TRENDS IN SOUTHEAST ASIA 
The ISEAS - Yusof Ishak Institute (formerly Institute of Southeast Asian Studies) is an autonomous organization established in 1968. It is a regional centre dedicated to the study of socio-political, security, and economic trends and developments in Southeast Asia and its wider geostrategic and economic environment. The Institute's research programmes are grouped under Regional Economic Studies (RES), Regional Strategic and Political Studies (RSPS), and Regional Social and Cultural Studies (RSCS). The Institute is also home to the ASEAN Studies Centre (ASC), the Temasek History Research Centre (THRC) and the Singapore APEC Study Centre.

ISEAS Publishing, an established academic press, has issued more than 2,000 books and journals. It is the largest scholarly publisher of research about Southeast Asia from within the region. ISEAS Publishing works with many other academic and trade publishers and distributors to disseminate important research and analyses from and about Southeast Asia to the rest of the world. 


\section{WHY DID BERSATU LEAVE PAKATAN HARAPAN?}

Wan Saiful Wan Jan 
Published by: ISEAS Publishing

30 Heng Mui Keng Terrace

Singapore 119614

publish@iseas.edu.sg

http://bookshop.iseas.edu.sg

(C) 2020 ISEAS - Yusof Ishak Institute, Singapore

All rights reserved. No part of this publication may be reproduced, stored in a retrieval system, or transmitted in any form, or by any means, electronic, mechanical, photocopying, recording or otherwise, without prior permission.

The author is wholly responsible for the views expressed in this book which do not necessarily reflect those of the publisher.

\section{ISEAS Library Cataloguing-in-Publication Data}

Name(s): Wan Saiful Wan Jan.

Title: Why did Bersatu leave Pakatan Harapan? / by Wan Saiful Wan Jan. Description: Singapore : ISEAS - Yusof Ishak Institute, June 2020. Series: Trends in Southeast Asia, ISSN 0219-3213 ; TRS10/20 | Includes bibliographical references.

Identifiers: ISBN 9789814881890 (paperback) | ISBN 9789814881906 (PDF)

Subjects: LCSH: Parti Pribumi Bersatu Malaysia. | Pakatan Harapan (Malaysia) | Electoral coalitions-Malaysia. | Malaysia-Politics and government. | Malaysia-Ethnic relations-Political aspects.

Classification: LCC DS501 I59T no. 10(2020)

Typeset by Superskill Graphics Pte Ltd

Printed in Singapore by Markono Print Media Pte Ltd 